\title{
Práticas disciplinares inauguradas com a República no ensino secundário paranaense
}

\author{
Serlei Maria Fischer Ranzi * e Maclovia Corrêa da Silva **
}

Resumo: Neste artigo, faz-se a análise do processo de criação e apropriação de práticas disciplinares no Ginásio Paranaense, no período de 1896 a 1930. A discussão tem como fundamento o poder disciplinar que se interpôs entre os sujeitos envolvidos, tanto na sala de aula quanto no recinto do estabelecimento responsável pela organização do curso secundário regular, no Estado do Paraná. Eram os membros da Congregação e o Diretor os responsáveis por interpretar e cumprir o regulamento escolar, de modo que as faltas correspondessem às penas, e estas fossem capazes de "adestrar" os "delinqüentes". As práticas disciplinares inauguradas juntamente com a República dependeram da constante regulação de sanções e competências. A contribuição desta análise foi acrescentar ferramentas à discussão existente, que explicam, no tempo, a mobilização de relações de poder instauradoras do espaço escolar como palco de vivências cotidianas.

Palavras-chave: ensino secundário; relações de poder; normas disciplinares.

Disciplinary practices in high school teaching inaugurated with the Republic in Paraná - Brazil

\begin{abstract}
This paper brings an analysis of the creation and application of disciplinary practices at an institution called Ginásio Paranaense from 1896 to 1930. The discussion has its bases on the disciplinary power interposed between the kinds of subjects involved, both in the classroom environment and and in the institution responsible for high school organization in Paraná. The members of the Congregation and the Principal were the people responsible for interpreting and accomplishing the school regiment in such a way that flaws would correspond to penalties, so that they would be able to "tame" the "delinquents". The disciplinary practices inaugurated with the Republican government depended on the constant regulation of penalties and competences. This analysis was useful in adding tools to the present discussion by explaining the mobilization of power relations which, along time, were disciplinary and characterized schools as stages for daily life experiences.
\end{abstract}

Key words: high school teaching; power relations; disciplinary rules.

* Professora do Departamento de Teoria e Prática de Ensino e do Programa de Pós-Graduação em Educação do Setor de Educação da Universidade Federal do Paraná, Brasil. serlei@ufpr.br

* Professora do Programa de Pós-Graduação em Tecnologia da Universidade Tecnológica Federal do Paraná, Brasil.macloviasilva@utfpr.edu.br 
Este artigo tem por objetivo analisar o processo de criação e de apropriação de regras e normas disciplinares no Ginásio Paranaense - estabelecimento responsável pela organização, no Estado do Paraná, do curso secundário regular , que funcionou com a preocupação de se adequar às exigências de equiparação ao Ginásio Nacional ${ }^{1}$. Em outro texto (Ranzi; Silva, 2006), já abordamos os esforços do Ginásio Paranaense para conseguir a equiparação ao Ginásio Naci$\mathrm{onal}^{2} \mathrm{e}$ as medidas tomadas pelos dirigentes para a manutenção desse privilégio. A equiparação significava a legitimação do ensino secundário e, nesse sentido, os ginásios estaduais tinham regras a cumprir; no entanto, aberturas e lacunas na lei de equiparação estimulavam o descontrole e o descumprimento de tais regras em muitos estados brasileiros.

Os estudos centrados nos Ginásios estaduais revelam como as políticas nacionais foram apropriadas no local e evidenciam as singularidades para estabelecer um itinerário escolar regular e normal, ou seja, a frequiência diária dos alunos em um estabelecimento de ensino, sem interrupção dos estudos, respeitando um tempo escolar e uma seriação para a conclusão do ensino secundário. Um desafio que o Ginásio teve que enfrentar, nas quatro décadas que marcaram a sua organização e a sua consolidação como escola secundária regular, foi a permanência, durante toda a primeira República, da dupla organização do ensino que permitia ao aluno freqüentar o ensino regular $/ \mathrm{serial}^{3}$ ou optar pela preparação não regular/informal para prestar exames parcelados. Esta segunda opção possibilitava ao estudante fazer um ou dois anos do curso regular para, em seguida, escolher algumas disciplinas que julgava mais adequadas para concorrer ao ensino superior, em um curso de sua preferência. Um dos objetivos dos dirigentes educacionais era impedir esse percurso de formação dispersiva e fragmentada; para tanto, eles investiram num espaço próprio para a escola secundária, iniciaram um processo para dificultar os exames parcelados e defenderam a formação integral dos jovens. Para dissuadir a procura

I. Este artigo é parte do projeto denominado: "O ensino secundário no Paraná I892-1930: a organização e a constituição de um campo pedagógico na rede pública paranaense".

2. Os requisitos mínimos para a equiparação dos ginásios estaduais ao Ginásio Nacional podem ser assim resumidos: lentes concursados efetivos e lentes concursados substitutos, condições patrimoniais para o funcionamento do colégio, número mínimo de alunos, disciplinas obrigatórias ofertadas em séries regulares seguindo o programa do Colégio D. Pedro II. Para manter o privilégio da equiparação, o colégio submetia-se à fiscalização federal que vistoriava principalmente o cumprimento do programa, as cargas horárias e os exames gerais do curso seriado e dos exames preparatórios. Os procedimentos disciplinares não eram objeto de análise dos inspetores federais.

3. Foucault (2003, p. 126) atribui positividade ao ensino serial e regular, o qual determina lugares individuais e torna possível o controle de cada um e o trabalho simultâneo de todos. O autor admite, ao mesmo tempo, que o ensino serial e regular organiza uma economia do tempo de aprendizagem. 
pelos parcelados era preciso convencer os alunos e os pais de que estava em jogo uma nova concepção de espaço e de tempo escolar.

A contribuição desta análise é acrescentar, à discussão existente, ferramentas que explicam a mobilização, no tempo, de relaçôes de poder que permitiram constituir o espaço escolar como um lugar e um território. A instituição escolar ocupa um espaço que se torna um lugar, como resultado da ocupação e da utilização pelo ser humano.

Um lugar específico, com características determinadas, aonde se vai, onde se permanece certas horas de certos dias, e de onde se vem [...]. Ao mesmo tempo, essa ocupação do espaço e sua conversão em um lugar escolar, leva consigo sua vivência como território, por aqueles que com ele se relacionam (Viñao, 2005, p. 17).

A configuração do espaço escolar como um lugar específico e um território demarcado, na acepção de Viñao, ocorre na convivência cotidiana, na relação entre o interno e o externo escolar, entre o permitido e o proibido, entre o ocultamento e a visibilidade.

Neste estudo, estamos também tratando das relações de poder disciplinar institucional no ensino secundário, no período de 1896 a 1930. Buscamos dar visibilidade às produções e às apropriações de práticas cotidianas ${ }^{4}$, a partir dos procedimentos adotados no Ginásio, na composição de corporeidades-modos de agir, na definição de espaços para os integrantes de sexos opostos, nos usos do tempo escolar e nas manifestações de práticas desviacionistas, sobretudo com o objetivo de captar, nas ações, o movimento (Certeau, 1995, p. 250).

Para analisar especificamente as sanções disciplinares no Ginásio, destaca-se o conjunto de atas da Congregação e os editais de suspensão e advertências de alunos. O acesso às atas, que pertencem ao período de 1896-1911, permitiu acompanhar as ações da Congregação para definir, punir, organizar o uso do espaço escolar, pois elas estão repletas de detalhes, de informações sobre as decisões, sobre recuos e disputas na definição de procedimentos para demarcar a circulação e a ação dos sujeitos no interior e nas cercanias da escola. Para os anos de 1919 a 1928, há uma lacuna na documentação específica da Congregação, mas mesmo assim foi possível analisar algumas mudanças nos procedimentos disciplinares, pelo acesso a um conjunto de documentos que embasaram, principalmente, o "olhar hierárquico". Um segundo conjunto de atas da Con-

4. Estamos tomando as práticas disciplinares como integrantes das práticas escolares na sua acepção mais ampla, ou seja, como práticas culturais (Certeau, 1994). Nesse sentido, analisamos a constituição do poder disciplinar e as estratégias delineadas para produzir efeitos nas ações dos sujeitos a partir de relações estabelecidas nos intramuros da escola. 
gregação e os editais (que divulgavam normas e decisões sobre o cotidiano da escola) do final do período estudado (1929-30) possibilitaram uma análise relacional das mudanças nas normas e nas regras do Ginásio em dois intervalos de tempo: um, de 1896-1911, e outro, de 1929-30, sumarizados em quatro quadros analisados no interior deste texto.

Além das atas da Congregação e dos editais, foram utilizados jornais, relatórios, cartas e documentos institucionais do Ginásio Paranaense, os quais ampliaram a compreensão sobre os fatores que concorreram para a mudança de percepção da sociedade em relação ao papel da escola secundária regular.

\section{Relações de poder disciplinar construídas no Ginásio Paranaense}

O Ginásio Paranaense - a autoridade máxima estadual na área da educação secundária - era um braço do Ginásio Nacional e possuía um prédio adequado às suas funçóes. As regras disciplinares nas salas de aula, nas salas de professores, nas salas de reuniōes, nos corredores, no pátio e nos muros provocavam transformações nos ambientes e nos comportamentos. Uma organização peculiar do poder disciplinar delimitava o andamento dos trabalhos e das palavras verbalizadas ou escritas, avançando para além do caráter negativo do poder repressivo: consensos, interesses, olhares, forças e posiçōes funcionais.

Quem detinha o poder disciplinar? Professores ${ }^{5}$, diretor, inspetores, governo estadual, governo federal, pais de alunos eram os protagonistas que faziam circular a potencialidade do poder disciplinar. A hierarquia, seja por meio de mudanças de postos, por mudanças de atribuições, ou seja pela verticalização, permite examinar como o poder foi exercido durante o período de implantação do ensino regular (1892-1930).

A Congregação, até 1911, manteve a rotina quanto ao cumprimento do seu papel de órgão decisório nas questôes internas do Ginásio. A sua atuação para a imposiçăo de penas disciplinares foi marcante, tendo em vista a freqüência de convocaçōes e o tempo destinado para definir padrōes de comportamentos e de atitudes. No entanto, esse poder foi sendo distribuído, após 1915, para outros níveis hierárquicos. Ao Diretor do Ginásio couberam decisões até então tomadas somente pela Congregação, como, por exemplo, punições aos alunos que não envolvessem processos disciplinares. Nesses casos, a punição poderia implicar suspensão por um ou dois anos.

Os efeitos do poder disciplinar imposto aos alunos que cometiam faltas, resultavam em puniçôes com fins corretivos. Algumas advertências eram repe-

5. As denominações atribuídas ao corpo docente do Ginásio variaram: professores catedráticos, lentes catedráticos, professores substitutos, lentes e professores. Neste artigo os termos foram usados indistintamente, tal qual eles foram referenciados nos documentos. 
tidas, contestadas, outras aceitas. Conflitos e contradições interpuseram-se entre as regras e os modos de aplicação delas.

A (re) distribuição do poder da Congregação consolidou-se com a criação de comissões com a função de estudar e dar pareceres para as diversas demandas da área educacional. Todavia, as decisões finais aconteciam por meio de votos dos membros da Congregaçãa ${ }^{6}$; e essa prática, bem como as que seguem, manteve-se até 1930:

a) No início do ano letivo, em geral em março, e no final, em novembro, eram definidos os programas das matérias, o calendário escolar, as datas dos exames e a situação dos alunos considerados reprovados por falta.

b) Ao longo do ano escolar, a Congregação constituía comissões de bancas examinadoras de concursos e de exames, bem como aquelas que deveriam dar parecer sobre obras didáticas propostas para o ensino no Ginásio e para a rede de educação popular do Estado do Paraná.

c) Cabia a ela deliberar sobre questôes disciplinares cotidianas do Ginásio e votar as puniçôes para lentes, professores, alunos e outros membros da comunidade escolar, oportunizando aos envolvidos atos de defesa.

d) Os membros analisavam as mudanças na legislação federal e decidiam sobre as adequaçôes necessárias ao cotidiano do Ginásio. Discussões pedagógicas ocorriam eventualmente nas reuniōes.

Os lentes do Ginásio ${ }^{7}$ e o Diretor compunham o corpo deliberativo da Congregação. Os professores interinos eram convidados para as sessóes, porém somente tinham direito a voto quando se tratava de assunto referente às suas aulas.

\section{Mecanismos de disciplinamento no cotidiano escolar: os primeiros tempos do Ginásio - |896-1911}

Nos anos iniciais, o Ginásio funcionou em dois prédios: um deles provisório até 1904; depois, em um prédio construído especificamente para esse grau

6. O papel da Congregação começou a ser definido com a criação do Ginásio, pelo Decreto n 3 , de 14 de outubro de | 892. Por meio das análises das atas da Congregação observa-se um rigor no cumprimento de suas funções, principalmente no que tange ao poder disciplinar. $\bigcirc$ disciplinamento e as situações que o tornaram real abriram possibilidades para deslocar esse poder da Congregação, para ser, a partir de 1915, retomado na figura do Diretor do Ginásio.

7. O corpo docente do Ginásio Paranaense era constituído por lentes catedráticos concursados e professores interinos nomeados. A cadeira de Ginástica era preenchida por um mestre nomeado. 
de ensino. No entanto, durante 18 anos ele dividiu seu espaço com a Escola Normal. Nesse espaço compartilhado, as regras foram sendo impostas, reavaliadas, construídas, mas mantendo, de modo concomitante, um teor punitivo e "civilizador".

As delimitações de circulação e as adequações de espaço oferecidas pelo poder público para a educação formal foram rigidamente controladas e os culpados dos desvios, punidos. Espaço e tempo estavam conjugados. A permanência de alunos no interior do estabelecimento 15 minutos antes do início e 15 minutos após o término das aulas era vedada. O mecanismo da campainha sinalizava a ordem de entrada, e nesse sentido o controle foi se aprimorando. Ao primeiro toque, entravam os professores, seguidos pelos meninos, ao soar o segundo; e a terceira batida liberava a entrada das meninas. $\mathrm{O}$ inverso acontecia no final das aulas: primeiro saíam as meninas, em seguida os meninos e, por fim, os professores.

Pode-se inferir que as práticas disciplinares no Ginásio mantinham a lógica de distribuir os indivíduos em espaços fechados e heterogêneos, com lugares especificados. Como na sala de aula as turmas do Ginásio eram compostas por alunos de ambos os sexos, as alunas ficavam separadas numa fila lateral ou nas primeiras carteiras, em frente à mesa do professor (ver Figura 1).

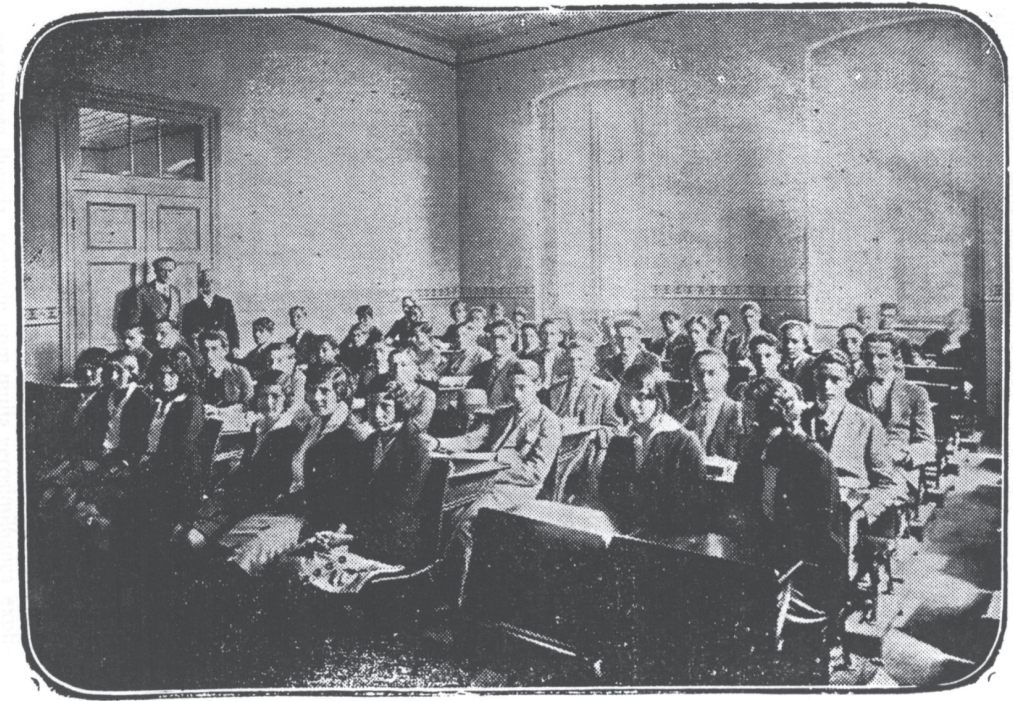

Historia Universal-3..$^{\circ}$ Anno-2. ${ }^{\text {a }}$ Turma, lente cathedratico Dr. Cyro Moraes de Castro Vellozo

Fonte: Annuario do Gimnásio Paranaense, n. I, anno I, 1929.

Figura I 
O rigor no controle dos corpos abrangia, inclusive, a prerrogativa de proibir conversas entre os integrantes de sexos opostos - no interior do colégio e nas imediações -, que perdurou durante todo o período estudado. Editais eram afixados e distribuídos pelas paredes, para lembrar, sobretudo para as meninas, as regras do regulamento. Todos esses indícios de práticas lembram os mecanismos citados por Foucault (2003, p. 121-42) e apropriados pela escola, pois cada indivíduo ocupava um lugar ao mesmo tempo funcional e hierarquizado, formando um quadro espacial no qual se distribuía a multiplicidade de indivíduos, para tirar deles o maior número de efeitos possíveis ao longo do tempo.

A presença feminina nas salas de aula - já desde o início do século XX sempre em número inferior - variava de 2 a 18 alunas. Em 1929, registrava-se um número maior, mas o total de alunos matriculados no Ginásio também havia crescido muito.

No trabalho autobiográfico de América Sabóia (1978), a autora relembra a disciplina experienciada no Ginásio Paranaense e na Escola Normal, que era permeada por relaçóes de confiança que se estabeleciam entre as alunas e a inspetora das moças. Havia um espaço para negociação entre elas como, por exemplo, a possibilidade, em caso de horário vago, de as alunas ausentarem-se da escola; todavia, com o compromisso assumido de retornar para a aula seguinte. Brincadeiras moderadas eram permitidas: "cantar, dançar e pregar peças umas nas outras" (Sabóia, 1978, p. 82). Mesmo assim, no seu olhar, os rapazes desfrutavam de mais liberdade de expressão, fazendo uso de brechas encontradas em práticas desviacionistas ${ }^{8}$, tais como algazarras "e os famosos 'enterros' dos professores e administradores em protesto à atuação dos mesmos" (Sabóia, 1978, p. 83). Esses dados de memória possibilitam um olhar sobre o processo de inculcação cultural de determinados papéis tidos como naturais e próprios da condição masculina e, ao mesmo tempo, impróprios para a natureza feminina.

8. Michel de Certeau (1994, p. 79) nega a passividade do sujeito submetido às práticas do espaço. Para ele, existem milhares de modos de jogar e desfazer o jogo do outro num espaço previamente delimitado, os quais "caracterizam a atividade, sutil, tenaz, resistente, de grupos que, por não ter um próprio, devem desembaraçar-se em uma rede de forças e de representações estabelecidas. [...] Nestes estratagemas de combatentes existe uma arte dos golpes, dos lances, um prazer em alterar as regras de espaço opressor".

9. Santos Souza (2004, p. I0I-103), em sua pesquisa sobre a condição da mulher professora na instrução pública em Curitiba - 1903-1927 -, observou que as representações predominantes na sociedade marcavam as professoras com reservas morais e como portadoras de um acanhamento naturalizado, pois se incutia nelas uma espécie de mundo virtuoso. Como representantes do mundo feminino, elas naturalizavam diferentes papéis, partindo do sexo como algo dado. Ao mesmo tempo já se observavam algumas resistências como, por exemplo, a reivindicação de a mulher atuar também em outros meios que não a sala de aula e o trabalho doméstico. 
A circulação das alunas era vigiada, com limites bem definidos. A autora reforça o entendimento de que o único espaço comum de ambos os sexos era a sala de aula. Saguão, pátio externo, secretaria, sala do Diretor, escadas, eram ambientes onde se circulava somente com permissão. Podemos caracterizar como um avanço, em relação a alguns estados brasileiros, a freqüência das integrantes do sexo feminino no curso ginasial secundário público; entretanto, a vigilância e os limites impostos no convívio entre os sexos opostos mostram que a sociedade paranaense estava atenta em relação à polidez e à moralidade ${ }^{9}$, aspectos previstos no regulamento escolar e cobrados pela sociedade.

Ainda na consideração da segmentação do espaço escolar, no Ginásio destaca-se o singular e intocável espaço da torre, freqüentado exclusivamente pelo Diretor, local de boa visibilidade, na frente do prédio, onde estava definida a entrada dos meninos. A sala do Diretor, estrategicamente na torre central, permitia que ele visse sem nunca ser visto. Aquele que está sendo visto nunca tem a certeza se está mesmo sendo vigiado ${ }^{10}$. Além disso, o espaço escolar era controlado por meio de outras estratégias e sujeitos:

a) Pelo professor, que tinha autoridade para advertir o aluno isoladamente; e, em caso de reincidência, poderia repreendê-lo publicamente na sala de aula ou encaminhar o caso ao Diretor.

b) Pelo inspetor/ra de alunos, que podia fazer denúncia de mau comportamento no pátio e nas imediações da instituição.

O poder disciplinar não era, portanto, centralizado. Encontrava-se perifericamente distribuído e multiplicado em toda parte e ao mesmo tempo. Reaçōes, reincidências são aspectos da prática da liberdade de resistir, de contestar, de enfrentar, de negar, de organizar motins, de anarquizar e de buscar brechas na normalização.

Cabia à Congregação definir as penas para cada caso de reclamação, fossem elas oriundas do Diretor, de professores, de inspetores ou mesmo de alunos. As situaçōes de indisciplina não resolvidas pelo professor e as mais graves, como ofensa à moral, injúrias verbais ou escritas, ameaças ou tentativas de agressão ou violência, deveriam ser submetidas pelo Diretor à Congregação. Esta, depois de certificar-se da "verdade", procederia às indagaçôes. Ouvindo o acusado, ela poderia impor a pena de suspensão da frequiência às aulas e da submissão aos exames por um ou dois anos. Em caso de agressão ou violência, o nominado "delinqüente" era punido com a expulsão sumária do Ginásio.

10. Esse exemplo ilustra a forma como o poder disciplinar mantém-se na invisibilidade para funcionar, e dessa maneira a invisibilidade ressalta a visibilidade daqueles que a ele se sujeitam, reforçando a constância e a permanência do poder (Pogrebinschi, 2004, p. 191). 
As deliberações da Congregação davam-se no sentido de corrigir os indisciplinados através de penas de suspensão gradativas: inicialmente de 15 dias, depois um mês, chegando até dois anos. Quando o aluno assumia o erro e prontificava-se a não repetir mais a indisciplina, os membros da Congregação tinham a prerrogativa de reavaliar a pena.

Essa prática foi observada até 1911 e, no que concerne ao rigor das penas, muitos alunos foram suspensos por meses, por anos e, muitos, expulsos. Se havia um interesse manifestado da instituição em consolidar o ensino regular, por que os seus pares adotavam tanto rigor nas penas disciplinares? $\mathrm{O}$ mecanismo de austeridade do poder disciplinar teria uma função nesse processo de consolidação denominada por Foucault (2003, p. 143) de "adestramento". Assim, compreende-se a forma como a Congregação resolvia ações indisciplinares de grupos de alunos. O "adestramento" dava-se pela punição dos "cabeças do motim", atribuindo-lhes responsabilidades e penas diferenciadas. Levava-se em conta a natureza da participação e as virtualidades dos alunos. Se, porventura, os "cabeças" figuravam como reincidentes ${ }^{11}$, o castigo disciplinar, representado por uma pena de suspensão por dois anos ou expulsão do estabelecimento, reduziria desvios e serviria como corretivo.

Desse modo, a Congregação comparava, diferenciava, hierarquizava, homogeneizava e excluía. À medida que ela delegava, multiplicava e distribuía poderes para as hierarquias mais periféricas, o tempo e a frequiência das reuniões diminuíam. O poder disciplinar alterou-se e alterou seu entorno, mesmo com a resistência daqueles que queriam manter o status quo dos discursos "verdadeiros".

\section{Sanções disciplinares no Ginásio Paranaense: o papel da Congregação}

Na perspectiva de análise foucaultiana, nesta seção analisa-se o poder disciplinar no seu vasto campo de aplicação, marcado por técnicas, instrumentos, procedimentos e mecanismos institucionais particulares. Equilibrar os conflitos entre as regras delimitadoras de ação e a produção de "verdade" era uma arte praticada pela Congregaçãa ${ }^{12}$.

11. A Congregação levava a petição de alunos para discussão. Cita-se uma ocorrência analisada em 1900 de um ex-aluno que não foi absolvido da pena de expulsão por ser um caso de reincidência, e também porque "Si não fosse a mantida a deliberação respectiva à punição do supplicante, não seria tomado ao sério, como é mister, qualquer resolução tendente a reprimir abusos." (Ata da Congregação, de 13 de setembro de 1900).

12. Foucault (1989, p. 13) afirma que "há um combate "pela verdade" ou ao menos "em torno da verdade" - entendendo-se, mais uma vez, que por verdade ele não quer dizer "o conjunto das coisas verdadeiras a descobrir ou a fazer aceitar", "mas o conjunto das regras segundo as quais se distingue o verdadeiro do falso e se atribui ao verdadeiro efeitos espeć́ficos de poder...". 
Os Quadros 1a e 1b, a seguir, são sumarizaçōes dos registros encontrados nos livros de atas da Congregação. Neles estão descritos os casos analisados neste estudo, com a descrição do ocorrido, os participantes da ação e as penas atribuídas. Acompanhando as datas e as pautas das reuniốes da Congregação, percebe-se que havia bastante seriedade nas discussōes sobre as faltas e as penas. Eram levantadas as diversas facetas delas, com escolhas para ajustar o tipo de desrespeito às sanções.

Os resultados prováveis e as suas implicaçōes eram amplamente discutidos. A complexidade dos conflitos entre alunos, professores e inspetores exigia o detalhamento dos atos que iam contra as regras e o cumprimento da punição, como possível adestramento provindo das medidas tomadas. Decorria um tempo entre a tomada de ciência do fato, a análise, o julgamento e a decisão final, permeados por um ritual de inquirições, confissōes e contestaçôes. Queixas, motins, algazarras, denúncias verbais e escritas, desacatos, desrespeito, perturbação da ordem, injúrias, agressōes e mau comportamento diminuíam a produtividade dentro das salas de aula.

Pelo rigor com que a Congregação punia qualquer tipo de indisciplina, naquela época, o "adestramento" poderia ser um dispositivo para reduzir os desvios no processo de implantação de uma política de educação secundária.

Com as informações obtidas nas atas da Congregação e nos editais do Ginásio, sistematizamos, em quatro quadros, as sançōes disciplinares atribuídas aos alunos. Esses quadros representam dois momentos marcados pelo regime de equiparação $(1905 / 1917)$ e estão desdobrados em função das punições por faltas ocorridas no interior da sala de aula e no recinto do estabelecimento.

Entre 1896 e 1911, conforme os Quadros 1a e 1b, a Congregação reuniuse com freqüência para acolher denúncias de perturbação da ordem formuladas por inspetores, professores e alunos. A quebra das regras em sala de aula dizia respeito a desacatos à autoridade do professor, destacadamente em disciplinas de Línguas, Geografia e Aritmética.

Para ilustrar como um professor efetuava uma denúncia, destacamos o relato de um caso ocorrido em sala de aula que foi apresentado na reunião da Congregação, sob forma de representação, pelo lente de Francês:

Tenho a honra de levar ao vosso conhecimento, que fui obrigado, hoje, a expulsar da minha aula os seguintes alunos: Antonio Virgulino Brasil, Verginio de Oliveira Melo, Benjamim Leite, Bernardo Moreira Garcês e Aristides de Paula França. O menos incriminado é o senhor Aristides, peço-vos porém, todo o rigor para o Virgulino, o qual teve a audácia de me desafiar ao sahir da aula. Esta minha resolução só teve lugar depois de várias admoestações vãs, esses moços discutiam e falavam tão alto que 
me impediam de ouvir a leitura feita pelos outros (Atas da Congregação do Ginásio Paranaense, de 8 de outubro de 1896, p. 1).

Nesse caso, foi aventada a possibilidade de convocar esses alunos para serem ouvidos, todavia as decisões da Congregação asseguraram ao lente o direito de exigir o comportamento desejado, pois "a confiança na veracidade do professor não podia ser destruída pela contestação dos delinqüentes” (Ata da Congregação, de 7 a 9 de outubro de 1896).

Um dos instrumentos usados em julgamentos da Congregação era um interrogatório, feito pelos membros, para os acusados. Nesses casos, eram freqüentes a admissão do erro, o pedido de desculpas e a promessa, por parte dos alunos, de respeito às regras. Dessa forma, a Congregação adotava mecanismos de poder para absolver ou reduzir as sançôes, asseverando um adestramento mais suave, na medida em que isto significava continuar a praticar as regras, sem, entretanto, burlá-las.

Entretanto, havia ocasiões em que uma conversa não era suficiente para resolver situações de conflito. Consta, em atas da Congregação (1896-97), o

Quadro Ia. Sanções disciplinares atribuídas pela Congregação aos alunos do Ginásio Paranaense |896/19||

\begin{tabular}{|l|l|l|l|}
\hline $\begin{array}{c}\text { No interior da sala de } \\
\text { aula }\end{array}$ & \multicolumn{1}{c|}{ Tipo de falta } & \multicolumn{1}{c|}{ Tipo da pena } & Sujeitos envolvidos \\
\hline $\begin{array}{l}\text { Aulas de Língua } \\
\text { Estrangeira - Francês } \\
\text { e Latim }\end{array}$ & $\begin{array}{l}\text { Desafio ao lente, } \\
\text { desacato, fala em voz } \\
\text { alta, recusa a ler o } \\
\text { texto em voz alta }\end{array}$ & $\begin{array}{l}\text { 8 alunos - pena: } \\
\text { advertência e } \\
\text { suspensão de 2 meses }\end{array}$ & $\begin{array}{l}\text { Lente, aluno e } \\
\text { Congregação }\end{array}$ \\
\hline Aula de Português & $\begin{array}{l}\text { Desacato e intenção } \\
\text { de agredir o lente }\end{array}$ & $\begin{array}{l}1 \text { aluno - } \\
\text { impedimento de } \\
\text { entrar no Ginásio. } \\
\text { Pena: suspensão de 1 } \\
\text { ano }\end{array}$ & $\begin{array}{l}\text { Lente, aluno e } \\
\text { Congregação }\end{array}$ \\
\hline Aula de Geografia & $\begin{array}{l}\text { Perturbação da } \\
\text { ordem na sala de aula }\end{array}$ & $\begin{array}{l}\text { 6 alunos - pena: } \\
\text { suspensão de 15 a 30 } \\
\text { dias }\end{array}$ & $\begin{array}{l}\text { Lente, aluno e } \\
\text { Congregação }\end{array}$ \\
\hline Aula de Aritmética & $\begin{array}{l}\text { Injúrias e ofensas; } \\
\text { perturbação da } \\
\text { ordem na sala }\end{array}$ & $\begin{array}{l}5 \text { alunos - suspensão. } \\
\text { Pena: 15 dias a dois } \\
\text { anos }\end{array}$ & $\begin{array}{l}\text { Lente, aluno e } \\
\text { Congregação }\end{array}$ \\
\hline Banca de exames & $\begin{array}{l}\text { Desacato à banca de } \\
\text { exames }\end{array}$ & $\begin{array}{l}1 \text { aluno - proibição } \\
\text { de freqüentar o } \\
\text { Ginásio nas férias }\end{array}$ & $\begin{array}{l}\text { Lente, aluno e } \\
\text { Congregação }\end{array}$ \\
\hline
\end{tabular}

Fonte: Atas da Congregação do Ginásio Paranaense: | 896-1911 
caso de uma aluna ouvinte ${ }^{13}$ que permite exemplificar o encadeamento de forças e a criação de elos para evitar fragmentação do poder disciplinar. Muitas páginas foram redigidas para resolver esse caso da aluna sem matrícula regular, que agrediu verbalmente o professor de Matemática porque discordou da nota atribuída ao seu exame. A Congregação teve dificuldades para julgar essa ofensa, uma vez que o regulamento interno do Ginásio Paranaense não previa essa situação.

O professor ou lente da cadeira sentia-se bastante prejudicado, pois o Diretor estava demorando em tomar uma posição que lhe assegurasse a autoridade em sala de aula. Ele fez reclamaçóes, recusou continuar suas atividades e não aceitou voltar para o Ginásio enquanto a aluna agressora não fosse punida: "declaro-vos que não posso como homem de brio e dignidade comparecer no Gimnásio Paranaense onde fui injuriado sem ter até hoje a mais insignificante satisfação" (Atas da Congregação do Ginásio Paranaense, 1897, p. 9). O Diretor pretendia resolver a questão rapidamente, interpretando o regulamento sem levar em consideração a leitura que o professor fez do episódio e como este o atingiu. A reação do professor em busca de justiça levou o caso para a instância governamental.

Já que o Diretor e a Congregação não encontravam mecanismos regulamentares para penalizar a aluna, o próprio professor dirigiu a reclamação para o Governo do Estado ${ }^{14}$. Após diferentes interpretações da legislação, o "Governo" entendeu que se ela tinha sido autorizada a freqüentar as aulas, a fazer exames, então deveria ser considerada aluna e, conseqüentemente, ser julgada como os alunos regularmente matriculados. $\mathrm{Na}$ ata da Congregação de $01 \mathrm{fev}$. 1897, numa sessão reproduzida em diversas páginas, a aluna foi suspensa por dois anos.

A questão da punição da aluna "ouvinte" estava ligada aos limites e à legitimação de poder do professor no espaço da sala de aula. As análises interpretativas feitas para aquele ocorrido restringiam as açóes da Congregação no sentido de oferecer soluções que não interferissem na autoridade do professor. Galgar a escala hierárquica foi uma estratégia que resolveu o impasse, mas, ao mesmo tempo, provocou uma situação incômoda e ocasionou uma dessimetria

13. Segundo o Decreto Lei n 3, de I 8 de outubro de I 892, no artigo I I3, o Ginásio admitia alunos ouvintes: "Nas aulas serão admittidas todas as pessoas morigeradas que quizerem frequentar como ouvinte precedendo licença do director". A legitimação acontecia por meio de um cartão assinado pelo Diretor, o qual perdia sua validade em caso de mau procedimento. Todavia, os lentes podiam também, independente dessa licença, admitir pessoas sem vínculos nas suas aulas (Paraná, p. 455).

14. A legislação previa a possibilidade de a Congregação do Ginásio Paranaense recorrer em última instância ao Governo do Estado (Regulamento da Instrução Pública do Estado do Paraná, I897, capítulo IX, artigo I76). 
de forças. A singularidade do procedimento apontou para uma situação até então não enfrentada pela Congregação nas relaçôes de forças, uma vez que o poder "todos o possuem, ao mesmo tempo em que ninguém o detém" (Pogrebinschi, 2004, p. 189). Essa situação mostra também como a flexibilidade do poder aflora sobre esses extremos, e os "sujeitos" - professores, diretores - ora se encontram na posição de mando, ora na de subserviência.

O Quadro 1 b também foi elaborado com dados extraídos das atas da Congregação e apresenta situações de comportamentos indisciplinares no recinto do estabelecimento como algazarras, distúrbios e motins que envolviam as figuras do porteiro, do contínuo, do inspetor de alunos; e as penas incidiam em suspensão e expulsão, tal como as transgressões no interior da sala de aula.

Quantitativamente, os Quadros 1a e 1b apontam para delitos referentes às relaçôes entre seres humanos que se encontravam naquele momento em diferentes posições na escala hierárquica social: desacatos ao professor, desafios de forças em um ambiente escolar e perturbação da ordem. Inspetores, professores e Diretor procuravam resolver os conflitos dentro de seus territórios até o ponto em que, obedecendo a uma distribuição de forças, fosse preciso circular a idéia de poder pela instituição.

A freqüência de alunos e alunas compartilhando o mesmo espaço acentuava o rigor e a preocupação com as relações de gênero, visíveis nas formas da vigilância e, em certa medida, nas punições. Sobressai o poder da Congregação na decisão de um conflito entre alunas e um aluno, que suscitou uma intensa discussão. De um lado, as vozes das alunas denunciavam as injúrias e palavras immoraes recebidas de um aluno e, de outro, negava-se esse ato. No meio desse embate, a Congregação começa a fazer uso de técnicas de poder: inquirições, confissões e defesa. $\mathrm{O}$ acusado não conseguiu provar a sua inocência e foi suspenso por dois anos (Atas da Congregação do Ginásio Paranaense, 18 de maio de 1897, p. 1).

As fontes analisadas permitem inferir que, na construção de práticas no espaço do Ginásio Paranaense, os mecanismos de coação e de controle eram confrontados pelos sujeitos, ensejando por um lado o conformismo e a resignação e, por outro, as reações e as diferentes formas de apropriação de códigos; nesse caso, aqueles próprios da escola (Chartier, 1996, p. 70).

\section{A construção do papel do diretor como gestor e a (re)organização das regras disciplinares}

Os anos iniciais do Ginásio foram marcados pela tentativa de colocá-lo de acordo com as regras criadas para equiparação dos estabelecimentos de ensino secundário, e a legitimação delas ficou a cargo das Congregações. No Paraná, 
Quadro Ib - Sanções disciplinares atribuídas pela Congregação aos alunos no recinto do Ginásio Paranaense |896/191|

\begin{tabular}{|c|c|c|c|}
\hline $\begin{array}{c}\text { Fora da sala de } \\
\text { aula }\end{array}$ & Tipo de falta & Tipo da pena & Sujeitos envolvidos \\
\hline $\begin{array}{l}\text { Recinto do } \\
\text { estabelecimento }\end{array}$ & $\begin{array}{l}\text { Mau comportamento: } \\
\text { queixa do contínuo }\end{array}$ & $\begin{array}{l}1 \text { aluno - } \\
\text { pena: expulsão }\end{array}$ & $\begin{array}{l}\text { Congregação e } \\
\text { aluno }\end{array}$ \\
\hline $\begin{array}{l}\text { Recinto do } \\
\text { estabelecimento }\end{array}$ & $\begin{array}{l}\text { Mau comportamento: } \\
\text { queixa do contínuo }\end{array}$ & $\begin{array}{l}2 \text { alunos - pena: } \\
\text { suspensão por } 60 \text { dias }\end{array}$ & $\begin{array}{l}\text { Contínuo, } \\
\text { professores e } \\
\text { alunos }\end{array}$ \\
\hline $\begin{array}{l}\text { Entrada do } \\
\text { Ginásio }\end{array}$ & $\begin{array}{l}\text { Reincidência de mau } \\
\text { comportamento: queixa } \\
\text { do porteiro e do } \\
\text { contínuo }\end{array}$ & $\begin{array}{l}4 \text { alunos - pena: } \\
\text { expulsão }\end{array}$ & $\begin{array}{l}\text { Congregação, } \\
\text { professor, porteiro, } \\
\text { contínuo e alunos }\end{array}$ \\
\hline $\begin{array}{l}\text { Recinto do } \\
\text { estabelecimento }\end{array}$ & $\begin{array}{l}\text { Motim: distúrbios e } \\
\text { motivações }\end{array}$ & $\begin{array}{l}17 \text { alunos - pena: } \\
\text { suspensão de } 15 \text { dias } \\
\text { a } 2 \text { meses (a pena não } \\
\text { está clara) }\end{array}$ & $\begin{array}{l}\text { Congregação, } \\
\text { inspetor e alunos }\end{array}$ \\
\hline $\begin{array}{l}\text { Entrada do } \\
\text { Ginásio }\end{array}$ & $\begin{array}{l}\text { Mau comportamento: } \\
\text { queixa do porteiro }\end{array}$ & $\begin{array}{l}3 \text { alunos - pena: } \\
\text { admoestação e } \\
\text { suspensão por } 6 \\
\text { meses }\end{array}$ & $\begin{array}{l}\text { Porteiro, aluno e } \\
\text { Congregação }\end{array}$ \\
\hline $\begin{array}{l}\text { Na sala de espera } \\
\text { da Congregação }\end{array}$ & Algazarra & $\begin{array}{l}3 \text { alunos - pena: } \\
\text { suspensão por } 15 \text { dias }\end{array}$ & Lentes e alunos \\
\hline $\begin{array}{l}\text { Recinto do } \\
\text { estabelecimento }\end{array}$ & $\begin{array}{l}\text { Desrespeito para com o } \\
\text { inspetor }\end{array}$ & $\begin{array}{l}1 \text { aluno - pena: } \\
\text { suspensão por } 30 \text { dias }\end{array}$ & $\begin{array}{l}\text { Inspetor, } \\
\text { Congregação e } \\
\text { aluno }\end{array}$ \\
\hline $\begin{array}{l}\text { Recinto do } \\
\text { estabelecimento }\end{array}$ & $\begin{array}{l}\text { Mau procedimento: } \\
\text { queixa }\end{array}$ & $\begin{array}{l}4 \text { alunos - pena: } \\
\text { inquirição }\end{array}$ & $\begin{array}{l}\text { Congregação e } \\
\text { alunos }\end{array}$ \\
\hline $\begin{array}{l}\text { Recinto do } \\
\text { estabelecimento }\end{array}$ & $\begin{array}{l}\text { Palavras imorais ditas a } \\
\text { três alunas }\end{array}$ & $\begin{array}{l}1 \text { aluno - pena: } \\
\text { suspensão por dois } \\
\text { anos }\end{array}$ & $\begin{array}{l}\text { Alunos e } \\
\text { Congregação }\end{array}$ \\
\hline $\begin{array}{l}\text { Recinto do } \\
\text { estabelecimento }\end{array}$ & Queixa do inspetor & $\begin{array}{l}2 \text { alunos - pena: } \\
\text { suspensão por } 5 \text { e } 10 \\
\text { dias }\end{array}$ & $\begin{array}{l}\text { Inspetor, alunos e } \\
\text { Congregação }\end{array}$ \\
\hline $\begin{array}{l}\text { Recinto do } \\
\text { estabelecimento }\end{array}$ & Queixa do inspetor & $\begin{array}{l}1 \text { aluno - pena: } \\
\text { admoestação }\end{array}$ & $\begin{array}{l}\text { Inspetor, aluno e } \\
\text { Congregação }\end{array}$ \\
\hline
\end{tabular}

Fonte: Atas da Congregação do Ginásio Paranaense: |896-191। 
eram os diretores que deveriam presidir as reuniōes e simultaneamente assumir o cargo de Diretor Geral da Instrução Pública Estadual. Esse acúmulo de funções era exercido por professores do Ginásio ou por políticos de outras esferas burocráticas, os quais assumiam, por tempo indeterminado, os cargos. Ao analisar a lista de diretores (Straube, 1993, p. 128-9) e observar tanto o tempo de permanência deles no cargo quanto o nome de cada um, é possível entender os percalços pelos quais a instituição de ensino passou ${ }^{15}$. A direção foi marcada pela interinidade assumida por professores. Como era legal acumular funções, o Diretor podia indicar, quando necessário, um professor que o representasse.

Dois renomados diretores assumiram o Ginásio - gestão de Sebastião Paraná (1916-1920) e gestão de Lysimaco Ferreira da Costa (1920-1928) - nos tempos em que a credibilidade daquele nível de ensino aumentava em consonância com a obediência às regras. Com a presença mais efetiva dos diretores no cotidiano do Ginásio, o papel da Congregação redefinia-se sucessivamente, e as formas de julgamentos, punições e os tipos de falta desritualizavam-se e ajustavam-se às ações diligentes do Diretor. Entretanto, a comunidade e a imprensa atuavam conjuntamente no sentido de vigiar e controlar os denominados excessos de uso do poder. Seus nomes estavam envolvidos em polêmicas e ocupavam por várias semanas as manchetes de periódicos (Gazeta do Povo, Commércio do Paraná e $A$ República) de destaque na capital.

Na gestão de Sebastião Paraná, como Diretor do Ginásio e da Escola Nor$\mathrm{mal}^{16}$, a crítica dos periódicos incidia, num primeiro momento, sobre o afrouxamento de padrôes disciplinares e, num segundo momento, no desrespeito a algumas alunas. Ele foi acusado de espalhar tensão e desigualdades entre educadores e educandos. Houve também a solicitação pública de pais e irmãos para a abertura de inquérito a fim de apurar as queixas das alunas. $\mathrm{O}$ jornal assumiu e divulgou o resultado da investigação:

Nós dissemos, dizemos e affirmamos que o sr. Sebastião Paraná insulta as senhoritas normalistas, chamando-as em plena aula de 'vagabundas', 'desavergonhadas' e outros termos de egual quilate, improprios de um professor e revoltantes quando, como no caso, este professor se dirige a moças e moças de fina educação (Gazeta do Povo, 21 jun. 1919).

15. Nos períodos de pré-equiparação (1904 e 1916), essa realidade apresentou-se desigual. Havia uma preocupação estratégica em escolher diretores que possuíam boas relações políticas, como Victor Ferreira do Amaral, vice-presidente do Estado, e Sebastião Paraná, ex-deputado estadual, professor catedrático do Ginásio e Superintendente Geral do Ensino. Ambos permaneceram quatro anos no cargo para colocar o Ginásio nos moldes do Ginásio Nacional e montar os processos de equiparação em 1905 e 1917.

16. Entre 1904 e 1922, o prédio do Ginásio abrigava também o curso da Escola Normal, partilhando as instalações, o Diretor e os professores. 
Além de registrar esses desacatos, o jornal questionou a continuidade do Diretor no cargo.

Nesse debate público, outro periódico assumiu a defesa do caráter e da personalidade do Diretor, declarando que "de facto quem conhece o sr. Sebastião Paraná $[. .$.$] o caracteriza como sendo incapaz de offender por palavras ou$ outras, e quem quer que seja verá a improcedência desta acusação" (Commercio do Paraná, 18 jun. 1919).

$\mathrm{O}$ incidente culminou com a decisão de suspender por oito dias quatro alunas do Curso Normal. Todavia, o desfecho foi outro, pois as alunas suspensas usaram a tática do recuo para fugirem das sanções. Cientes de uma brecha das regras, elas se desculparam perante o Diretor e foram isentas da penalidade.

As dificuldades para colocar ordem na casa continuaram na gestão seguinte. Segundo um jornal local, o novo Diretor herdava problemas como a existência de um grupo de alunos "mal educados" e a freqüência, no mesmo local, de meninos de 11 anos até rapazes e moças de 20 anos.

Lysimaco Ferreira da $\operatorname{Costa}^{17}$, ao assumir o cargo de Diretor do Ginásio Paranaense e da Escola Normal em 1920, começou a sua gestão introduzindo uma série de mudanças, as quais foram noticiadas. Figuravam entre as novas ordens a entrada dos alunos em cordão de dois em dois; a proibição de permanecer no estabelecimento fora do horário das aulas; a interdição de formar grupos e ficar parado nas imediações do estabelecimento; e a obrigação das moças de "usar vestidos afogados, e até no mínimo, dois centímetros abaixo do joelho". A severidade dessas medidas foi questionada nos seguintes termos: "neste estabelecimento de ensino reina o regime do terror - medidas curiosas e draconianas..." (Gazeta do Povo, 20 abr. 1920).

No exercício da função como Diretor, a definição e a exigência do uso do uniforme em curto prazo evocaram reações adversas e contraditórias. As críticas mais relevantes para o uniforme masculino resumiam-se ao fato de ser "totalmente militar, caríssimo, cheio de peças inúteis, incommodo..." (Gazeta do Povo, 12 jul. 1920).

Outro aspecto desfavorável do uniforme, comentado pelo jornal, foi a relação entre a escolha do tecido e o clima da cidade. Para as condições climáticas era necessário o uso de sobretudos, e as cores interferiam na imagem do conjunto; e, ainda, quando chovia, o cenário mudava: "o espetáculo cresce em hilariedade: são mocinhos fardados, a fazerem continências, de guarda chuva aberto!!!..." (Gazeta do Povo, 12 jul. 1920).

17. Lysimaco Ferreira da Costa já foi objeto de análise em pesquisas que exploraram sua trajetória na construção de um projeto educacional e cultural (Ranzi; Silva, 2004; Abreu, 2007). 
Com uma população ginasiana crescente, os problemas ultrapassavam os muros da escola e abrangiam não somente aspectos de disciplina e de moral, como também de manutenção do patrimônio. A um pequeno grupo de maus alunos era imputado um conjunto de açôes insubordinadas. A imprensa enumerava os tipos de delitos condenáveis: o desrespeito constante de certos alunos aos professores; a formação de grupos de alunos que permaneciam nas imediaçōes do colégio e amedrontavam os transeuntes com algazarras e pedradas; a quebra de vidros das janelas e portas; a danificação constante do jardim e das árvores fronteiriças ao lado do edifício do Ginásio; e o "modo original" de certos alunos entrarem nas aulas "em carreiras", gritando, num barulho infernal, "levando pela frente portas, carteiras".

O debate externo à vida escolar do Ginásio, liderado por dois jornais, que se colocavam em posições opostas de ataque e de defesa ao Diretor, trazia à tona as relaçôes de poder. Além desse interesse externo à escola, outros fatores demonstram a importância que o Ginásio assumiu a partir da década de 1920, tais como: mudança de gestão, mudança da Escola Normal para prédio próprio em 1922, ampliação significativa das matrículas no curso regular ${ }^{18}$ e um decréscimo de matriculados nos exames preparatórios. Em 1920 foram 229 alunos matriculados, e em 1930 foram registradas 604 matrículas.

A vigilância externa ao Ginásio encabeçada por jornais, com a participação de pais e políticos, permitiu complementar a análise das regras de disciplinamento e acompanhar as mudanças de papéis da Congregação e do Diretor na instrumentalização dos dispositivos disciplinares. O desempenho das funções dos dois diretores que, juntos, exerceram durante doze anos o cargo máximo do Ginásio, criou as condições para consolidar a normalização disciplinar, seja no aspecto de zelo pelo estabelecimento, seja no respeito às regras ou na agilidade e eficiência das punições.

O papel da escola secundária regular, como expressão do lugar onde se articulam as práticas educativas, apresentava-se dentro da idéia de ordem e progresso, mediada pela ação de elites esclarecidas, que tinha no Paraná o intelectual e educador Lysimaco Ferreira da Costa como principal representante. Ao assumir -cumulativamente - o cargo de Diretor do Ginásio, da Escola Normal e o cargo de Diretor da Instrução Pública, ele parece ter chamado para si a organização de uma campanha pela causa educacional, constituindo objetos e estratégias de intervenção e credenciando a si mesmo como um quadro intelectual e técnico capaz de formular e executar políticas educacionais. Ele en-

18. Em 1926, o total de matrículas no externato foi de 374 alunos. Para atender à crescente demanda, foi necessário abrir duas turmas suplementares para o primeiro e para o segundo ano (Regimento do Colégio Modelo da República, Gazeta do Povo, I 4 fev. 1927, p. 3). 
controu mecanismos como a eficiência e a disciplina para "ajustar" os jovens às novas condições e valores de vida.

Essa postura colocou-o no conjunto de tantos outros intelectuais da época, os quais defendiam uma reação idealista contra tudo o que era identificado como tentativa de conturbação da ordem social (Carvalho, 1997, p. 122).

\section{Normalização disciplinar: agilidade e eficiência nas punições ( 1929- 1930)}

A manutenção de uma estrutura disciplinar para o segundo intervalo de tempo (que estamos analisando) está explicitada na forma de editais. Cabia ao Diretor resolver diretamente a maioria das punições, e a Congregação era acionada quando a gravidade dos atos requisitava. Além disso, foram criados mecanismos para desdobrar as decisões. Constituíram-se comissões, as quais também tinham autoridade para julgar e indicar penas sobre irregularidades no funcionamento interno do Ginásio, para dar pareceres sobre questôes do ensino.

$\mathrm{O}$ poder de decisão do Diretor para resolver as questões de mau comportamento, falta de disciplina e agressôes físicas era incontestável e direto. Para as faltas classificadas como leves, como, por exemplo, os casos de chamadas de atenção, havia a promessa de punição na reincidência. Foram identificadas poucas situaçôes de briga entre colegas e arruaças, ambas consideradas faltas mais graves. Merece destaque a singularidade do caso (Quadro 2b) em que o pai do aluno recorreu da decisão do Diretor, mas a Congregação reunida manteve e apoiou a punição.

As regras mais burladas, e que receberam punições, referiam-se ao tratamento social entre os indivíduos. Arremesso de pedras, maus tratos físicos e morais, socos, pontapés eram atos mais freqüentes no cotidiano escolar do que o uso inapropriado do chapéu e o fumo dentro da escola.

Ao comparar os Quadros 1a e 1b, já visualizados, e 2a e 2b, expostos a seguir, percebe-se que as penas de suspensão sofreram uma redução drástica, pois, entre 1896 e 1911, elas variavam entre dias, meses e anos, enquanto no período de 1929-30, as sançôes referiam-se a penas diárias e semanais, reduzidas para um intervalo de 3 a 8 dias, as quais eram afixadas em editais.

As suspensões ocorriam, com maior freqüência, nas aulas de Línguas Estrangeiras - Francês, Latim e Inglês - e, em segundo lugar, nas aulas de Aritmética e Matemática. Mantiveram-se, portanto, nos dois períodos, conforme os Quadros 1a e 1 b e 2 a e 2b, a Língua Estrangeira e a Aritmética como matérias de maior frequiência de indisciplina. Por quê? $\mathrm{O}$ que explica essa incidência? Em parte, ela pode ser explicada pelas relaçôes de ensino-aprendizagem entre professor e aluno e, em parte, pelas dificuldades em determinadas "matérias". Alguns documentos da década de 1920, referentes ao Ginásio, como 
Quadro 2a - Sanções disciplinares atribuídas aos alunos do Ginásio Paranaense durante as aulas - 1929/1930

\begin{tabular}{|c|c|c|c|}
\hline $\begin{array}{c}\text { No interior da sala } \\
\text { de aula }\end{array}$ & Tipo de falta & Tipo da pena & Sujeitos envolvidos \\
\hline $\begin{array}{l}\text { Aulas de Inglês, } \\
\text { Latim, Francês }\end{array}$ & $\begin{array}{l}\text { Mau comportamento, } \\
\text { briga com o colega, } \\
\text { desacato, conversas, } \\
\text { indisciplina }\end{array}$ & $\begin{array}{l}27 \text { alunos - pena: } \\
\text { suspensão de } 3 \text { a } 8 \\
\text { dias }\end{array}$ & $\begin{array}{l}\text { Alunos, professor e } \\
\text { Diretor }\end{array}$ \\
\hline Aulas de Português & $\begin{array}{l}\text { Mau comportamento, } \\
\text { indisciplina }\end{array}$ & $\begin{array}{l}3 \text { alunos - pena: } \\
\text { suspensão de } 3 \text { a } 8 \\
\text { dias }\end{array}$ & $\begin{array}{l}\text { Alunos, professor e } \\
\text { Diretor }\end{array}$ \\
\hline Aulas de Coreografia & $\begin{array}{l}\text { Mau comportamento, } \\
\text { indisciplina }\end{array}$ & $\begin{array}{l}4 \text { alunos - pena: } \\
\text { suspensão de } 3 \text { dias }\end{array}$ & $\begin{array}{l}\text { Alunos, professor e } \\
\text { Diretor }\end{array}$ \\
\hline $\begin{array}{l}\text { Aulas de Aritmética } \\
\text { e Matemática }\end{array}$ & $\begin{array}{l}\text { Mau comportamento, } \\
\text { indisciplina }\end{array}$ & $\begin{array}{l}14 \text { alunos - pena: } \\
\text { suspensão de } 3 \text { a } 4 \\
\text { dias }\end{array}$ & $\begin{array}{l}\text { Alunos, professor e } \\
\text { Diretor }\end{array}$ \\
\hline Aulas de Ginástica & $\begin{array}{l}\text { Mau comportamento, } \\
\text { indisciplina }\end{array}$ & $\begin{array}{l}1 \text { aluno - pena: } \\
\text { suspensão de } 3 \text { dias }\end{array}$ & $\begin{array}{l}\text { Aluno, professor e } \\
\text { Diretor }\end{array}$ \\
\hline Aulas de Geometria & $\begin{array}{l}\text { Mau comportamento, } \\
\text { indisciplina }\end{array}$ & $\begin{array}{l}1 \text { aluno - pena: } \\
\text { suspensão de } 3 \text { dias }\end{array}$ & $\begin{array}{l}\text { Aluno, professor e } \\
\text { Diretor }\end{array}$ \\
\hline Aulas de Química & $\begin{array}{l}\text { Mau comportamento, } \\
\text { indisciplina, } \\
\text { perturbação com } \\
\text { brinquedos }\end{array}$ & $\begin{array}{l}1 \text { aluno - pena: } \\
\text { suspensão de } 3 \text { dias }\end{array}$ & $\begin{array}{l}\text { Aluno, professor e } \\
\text { Diretor }\end{array}$ \\
\hline Aulas de Filosofia & $\begin{array}{l}\text { Mau comportamento, } \\
\text { indisciplina }\end{array}$ & $\begin{array}{l}2 \text { alunos - pena: } \\
\text { suspensão de } 4 \text { dias }\end{array}$ & $\begin{array}{l}\text { Alunos, professor e } \\
\text { Diretor }\end{array}$ \\
\hline
\end{tabular}

Fonte: Editais do Ginásio Paranaense: 1929-1930

cartas, bilhetes de pais de alunos e matéria jornalística também tratam do tema. O lente da cadeira de Inglez e Allemão recebeu cartas do Diretor para tomar providências quanto ao cumprimento da disciplina em sala de aula. Em relação ao lente da cadeira de Aritmética, pais e alunos manifestavam suas insatisfações sobre os conteúdos que ele cobrava nos exames, alegando que eles não tinham sido trabalhados em sala de aula ${ }^{19}$.

19. Citam-se, a seguir, duas reclamações: uma carta em termos confidenciais enviada para o Diretor, professor Lysimaco F. da Costa, por Manuel Zuckow. Apresenta queixa da conduta do professor de Aritmética, alegando perseguição aos membros de sua família. A fim de evitar um possível ato premeditado com seu irmão que já tinha sido reprovado pelo professor, ele se adiantou e pediu ao Diretor atenção ao caso (Zuckow, M. Carta de 08 dez. 1924). Em 1920, o Dr. Octavio F. do Amaral escreveu ao Diretor reclamando da prova escrita de Aritmética, que tinha questões dificeis, e da cobrança de conteúdos de álgebra que o professor não havia dado. Diz que, além do seu filho, outros alunos reclamaram e o fiscal nada fez (Amaral, O. F. Carta de 06 mar. 1920). 
Quadro 2b. Sanções disciplinares atribuídas aos alunos no recinto do Ginásio Paranaense - 1929/1930

\begin{tabular}{|c|c|c|c|}
\hline $\begin{array}{c}\text { Fora da sala de } \\
\text { aula }\end{array}$ & Tipo de falta & Tipo da pena & Sujeitos envolvidos \\
\hline Não consta o local & $\begin{array}{l}\text { Não consta no edital a } \\
\text { razão da falta }\end{array}$ & $\begin{array}{l}1 \text { aluno - pena: } \\
\text { suspensão de } 3 \text { dias }\end{array}$ & $\begin{array}{l}\text { Pai do aluno - recorreu } \\
\text { da decisão -, } \\
\text { Congregação e Diretor }\end{array}$ \\
\hline $\begin{array}{l}\text { Recinto do } \\
\text { estabelecimento }\end{array}$ & $\begin{array}{l}\text { Desrespeito ao inspetor } \\
\text { de alunos }\end{array}$ & $\begin{array}{l}1 \text { aluno - pena: } \\
\text { suspensão de } 3 \text { dias }\end{array}$ & Aluno, inspetor e Diretor \\
\hline $\begin{array}{l}\text { Nas imediações do } \\
\text { Ginásio }\end{array}$ & Arruaça & $\begin{array}{l}1 \text { aluno - pena: } \\
\text { suspensão de } 5 \text { dias }\end{array}$ & Aluno, inspetor e Diretor \\
\hline $\begin{array}{l}\text { Recinto do } \\
\text { estabelecimento }\end{array}$ & $\begin{array}{l}\text { Mau trato ao colega } \\
\text { menor }\end{array}$ & $\begin{array}{l}2 \text { alunos - pena: } \\
\text { suspensão de } 8 \text { dias }\end{array}$ & Alunos, Diretor \\
\hline No saguão & $\begin{array}{l}\text { Mau comportamento: } \\
\text { tocando gaita de boca e } \\
\text { dançando }\end{array}$ & $\begin{array}{l}1 \text { aluno - pena: } \\
\text { suspensão de } 3 \text { dias }\end{array}$ & Aluno, Diretor \\
\hline $\begin{array}{l}\text { Na área do } \\
\text { Ginásio }\end{array}$ & Uso de chapéu e fumo & $\begin{array}{l}5 \text { alunos - pena: } \\
\text { suspensão de } 3 \text { dias }\end{array}$ & $\begin{array}{l}\text { Inspetor, alunos e } \\
\text { Diretor }\end{array}$ \\
\hline $\begin{array}{l}\text { Recinto do } \\
\text { estabelecimento }\end{array}$ & Chapéu na cabeça & $\begin{array}{l}14 \text { alunos - pena: } \\
\text { chamada de atenção }\end{array}$ & $\begin{array}{l}\text { Inspetor, Diretor e } \\
\text { alunos }\end{array}$ \\
\hline $\begin{array}{l}\text { Recinto do } \\
\text { estabelecimento }\end{array}$ & $\begin{array}{l}\text { Falta de respeito para } \\
\text { com uma aluna }\end{array}$ & $\begin{array}{l}6 \text { alunos - pena: } \\
\text { suspensão de } 3 \text { dias }\end{array}$ & Alunos e Diretor \\
\hline $\begin{array}{l}\text { Recinto do } \\
\text { estabelecimento }\end{array}$ & $\begin{array}{l}\text { Passou mentol nos } \\
\text { olhos do colega }\end{array}$ & $\begin{array}{l}1 \text { aluno - pena: } \\
\text { suspensão de } 3 \text { dias }\end{array}$ & Alunos \\
\hline $\begin{array}{l}\text { Recinto do } \\
\text { estabelecimento }\end{array}$ & $\begin{array}{l}\text { Entrada de alunos na } \\
\text { sala de aula antes do } \\
\text { professor }\end{array}$ & Chamada de atenção & Alunos e Diretor \\
\hline Salão de espera & $\begin{array}{l}\text { Barulho e } \\
\text { desobediência à } \\
\text { inspetora de alunas }\end{array}$ & $\begin{array}{l}4 \text { alunas - pena: } \\
\text { suspensão de } 3 \text { dias }\end{array}$ & $\begin{array}{l}\text { Alunas, inspetora e } \\
\text { Diretor }\end{array}$ \\
\hline $\begin{array}{l}\text { Recinto do } \\
\text { estabelecimento }\end{array}$ & $\begin{array}{l}\text { Indisciplina e desacato } \\
\text { ao funcionário }\end{array}$ & $\begin{array}{l}1 \text { aluno - pena: } \\
\text { suspensão de } 5 \text { dias }\end{array}$ & $\begin{array}{l}\text { Aluno, funcionário e } \\
\text { Diretor }\end{array}$ \\
\hline $\begin{array}{l}\text { Nas imediações do } \\
\text { Ginásio }\end{array}$ & $\begin{array}{l}\text { Arremesso de pedra no } \\
\text { colega }\end{array}$ & $\begin{array}{l}1 \text { aluno - pena: } \\
\text { suspensão de } 8 \text { dias }\end{array}$ & Aluno, Diretor \\
\hline $\begin{array}{l}\text { Nas imediações do } \\
\text { Ginásio }\end{array}$ & Arremesso de pedras & $\begin{array}{l}3 \text { alunos - pena: } \\
\text { suspensão de } 3 \text { dias }\end{array}$ & Alunos, Diretor \\
\hline Nos corredores & Conversas em voz alta & $\begin{array}{l}\text { Chamada de atenção } \\
\text { das alunas }\end{array}$ & Aluno, Diretor \\
\hline No pátio & $\begin{array}{l}\text { Agressão ao colega } \\
\text { menor }\end{array}$ & $\begin{array}{l}1 \text { aluno - pena: } \\
\text { suspensão de } 3 \text { dias }\end{array}$ & Aluno, Diretor \\
\hline No pátio & $\begin{array}{l}\text { Luta corporal com o } \\
\text { colega }\end{array}$ & $\begin{array}{l}1 \text { aluno - pena: } \\
\text { suspensão de } 3 \text { dias }\end{array}$ & Aluno, Diretor \\
\hline $\begin{array}{l}\text { Nas imediações do } \\
\text { Ginásio }\end{array}$ & $\begin{array}{l}\text { Tentativa de impedir } \\
\text { colega de ir à aula }\end{array}$ & $\begin{array}{l}1 \text { aluno - pena: } \\
\text { suspensão de } 3 \text { dias }\end{array}$ & Aluno, Diretor \\
\hline No pátio & $\begin{array}{l}\text { Ataques com socos e } \\
\text { pontapés }\end{array}$ & $\begin{array}{l}2 \text { alunos - pena: } \\
\text { suspensão de } 5 \text { dias }\end{array}$ & Alunos, Diretor \\
\hline
\end{tabular}

Fonte: Editais do Ginásio Paranaense: 1929-1930 
Além disso, esse desinteresse dos alunos por determinadas cadeiras pode ser explicado pelos exames diferenciados para entrada em cada curso universitário. Os alunos freqüentavam o Ginásio até o segundo ou terceiro ano do curso e, a partir de então, começavam a desistir de algumas matérias que não thes seriam úteis, tais como: Álgebra, História Geral e do Brasil, Geografia e Línguas Estrangeiras, cujos saberes não faziam parte dos conteúdos exigidos nos exames para os cursos de Engenharia, Odontologia e Medicina.

Nos Quadros 2a e 2b, pode-se visualizar que o processo de normalização disciplinar se tornou mais ágil, eficiente e flexível quanto aos tipos de punição. Isso foi decorrente de um conjunto de fatores que contribuíram para consolidar o ensino regular; dentre eles, o segundo processo de equiparação (1917), o aumento gradativo no número de matrículas, a mudança na concepção do papel do gestor no Ginásio e, conseqüentemente, no papel da Congregação.

Nas práticas de disciplinamento configuradas no Ginásio Paranaense ao longo da Primeira República, estavam definidos os limites de ação dos sujeitos - alunos, professores, inspetores, contínuos e secretários - submetidos ao regulamento. $\mathrm{O}$ que este texto buscou mostrar foi o movimento das açōes observadas pelos dados do cotidiano escolar, evidenciando que a construção do significado da escola regular se deu na tensão que articulou tanto a capacidade inventiva de determinados indivíduos, quanto o papel da comunidade, produzindo constrangimentos e questionamentos sobre as convenções e as normas impostas no cotidiano do espaço escolar.

Por meio da vigilância nas salas de aula, nos corredores, nas salas de reuniões, nos arredores do prédio, era possível aplicar penas que não se restringiam aos alunos. Embora não tenha sido objeto de estudo nos limites deste texto, professores e demais funcionários também eram julgados e alguns punidos pelo não-cumprimento de regras.

A definição de procedimentos disciplinares e a sua aplicação no Ginásio, tanto no "recinto do estabelecimento" como "na sala de aula", são indícios de como as práticas disciplinares podem ser mapeadas e como elas podem revelar, no campo das representaçôes, as açôes dos indivíduos e suas relações com os dispositivos formalizados no interior das escolas.

Ao final da Primeira República, mais notadamente a partir da década de 1920, o ensino secundário no Ginásio Paranaense reunia condições para dar continuidade a uma etapa de aceitação/adesão à escolaridade e às suas normas e exigências. As tentativas de estabelecer um itinerário escolar regular e normal (frequiência diária dos alunos em um espaço escolar sem interrupção dos estudos, respeitando um tempo escolar e uma seriação para a conclusão do ensino secundário) foram convenções que no Ginásio Paranaense levaram pelo menos três décadas para serem parcialmente absorvidas. 


\section{Referências bibliográficas}

ABREU, Geysa S. A. A trajetória de Lysimaco Ferreira da Costa: educador, reformador e político no cenário da educação brasileira - final do século XIX e primeiras décadas do século XX. 2007. 221 f. Tese (Doutorado em Educação). Pontifícia Universidade Católica de São Paulo, São Paulo.

AMARAL, O. F. Carta para Lysimaco F. da Costa. Curitiba, 6 mar. 1920. 1 f. Memorial Lysimaco F. da Costa.

ANNUARIO. Gymnasio Paranaense. Curityba: Typografia João Haupt, n. 1, anno 1, 1929.

CARVALHO, Marta. Educação e política nos anos 20: a desilusão com a República e o entusiasmo da educação. In: LORENZO, H.; COSTA, W. A década de 1920 e as origens do Brasil moderno. São Paulo: Unesp, 1997. p. 115-132.

CERTEAU, Michel de. A invenção do cotidiano: artes de fazer. Petrópolis: Vozes, 1994.

CERTEAU, Michel de. A cultura no plural. Campinas-SP: Papirus, 1995.

CHARTIER, Roger. Estratégias e táticas. De Certeau y las “artes de fazer”. Buenos Aires: Editora Manantial, 1996.

COLEÇÃO Atas da Congregação do Ginásio Paranaense. 1896-1911. [Manuscrito].

COLEÇÃO Atas da Congregação do Ginásio Paranaense. 1929-1930. [Manuscrito].

EDITAIS do Ginásio Paranaense. 1929-1930. [Manuscrito].

FOUCAULT, M. A microfisica do poder. Rio de Janeiro: Graal, 1989.

FOUCAULT, M. Vigiar e punir: nascimento da prisão. Petrópolis: Vozes, 2003.

JORNAL A REPÚBLICA. Os sucessos do Gymnasio. Curytiba, 21 abr. 1920.

JORNAL GAZETA DO POVO. A crise e as innovaçôes: a introdução do uniforme militar no "Gymnasio Paranaense". Curytiba, 12 jul. 1920.

JORNAL GAZETA DO POVO. Gymnasio Paranaense ou collegio de freiras? Curytiba, 20 abr. 1920.

JORNAL GAZETA DO POVO. O Caso da Escola Normal. Curytiba, 21 jun. 1919.

JORNAL GAZETA DO POVO. Regimento do Colégio Modelo da República. Curytiba, 14 fev. 1927.

JORNAL O COMMERCIO DO PARANÁ. O caso do Gymnasio. Curytiba, 18 jun. 1919.

PARANÁ. Leis e decretos. Decreto n. 3. Decretos, Regulamentos, leis e actos do Estado do Paraná, 1890-1892. Coritiba: Typographia da Penitenciária do Estado, 1911.

PARANÁ. Leis e decretos. Regulamento da Instrução Pública do Estado do Paraná de 1897. Coritiba: Typographia da Penitenciária do Estado, 1911.

POGREBINSCHI, T. Foucault, para além do poder disciplinar e do biopoder. Lua Nova: Revista de cultura e política, São Paulo: CEDEC, n. 63, p. 179-201, 2004. 
RANZI, S.; SILVA, M. Múltiplos itinerários de um lente e diretor do Ginásio Paranaense. Revista História da Educação. Pelotas/RS: Editora UFPel, v. 8, n. 16, p.153-67, 2004.

RANZI, S.; SILVA, M. Questôes de legitimidade na primeira República: o ensino secundário regular e a equiparação do Ginásio Paranaense ao congênere federal. Educação, Santa Maria: Centro de Educação/UFSM, v. 31, n. 1, p. 133-52, 2006.

SABOIA, América da Costa. Curitiba de minha saudade: 1904-1914. Curitiba: Impresso, 1978.

SOUZA, C. dos Santos. A mulher professora na instrução pública de Curitiba (1903-1927) um estudo na perspectiva de gênero. 2004. 109 f. Dissertação (Mestrado em Educação) - Universidade Federal do Paraná, Curitiba.

STRAUBE, Ernani Costa. Do Liceo de Coritiba ao Colégio Estadual do Paraná: 1846-1993. Curitiba: Fundepar, 1993.

VIÑAO, A. Espaços, usos e funçôes: a localização e disposição física da direção escolar na escola graduada. In: BENSCOTA, M. L. A. (Org.). A História da Educação, arquitetura e espaço escolar. São Paulo: Cortez, 2005.

ZUCKOW, M. Carta para Lysimaco F. da Costa. Curitiba, 8 dez. 1924. 1 f. Memorial Lysimaco F. da Costa.

Recebido em 28 de janeiro de 2008 e aprovado em 02 de fevereiro de 2009. 